\title{
The PATHOLOGICAL EXPORT BOOM AND THE BAZAAR EFFECT How to SOLVE THE GERMAN PUZZLE
}

\author{
HANS-WERNER SINN \\ CESIFO WORKING PAPER NO. 1708 \\ CATEgory 7: TRAdE POLICY \\ APRIL 2006
}

An electronic version of the paper may be downloaded

- from the SSRN website:

- from the RePEc website:

www.SSRN.com

- from the CESifo website:

Www.RePEc.org

www.CESifo-group.de 


\title{
THE PATHOLOGICAL EXPORT BOOM AND THE BAZAAR EFFECT HOW TO SOLVE THE GERMAN PUZZLE
}

\begin{abstract}
Germany is the laggard of Europe, yet the country is world champion in merchandise exports. The paper tries to solve this theoretical and empirical puzzle by diagnosing a "pathological export boom" and a "bazaar effect". Excessively high wages defended by unions and the welfare state against the forces of international low-wage competition destroy too big a fraction of the labour intensive sectors and drive too much capital and labour into the capital intensive export sectors, causing both unemployment and excessive value added in exports. Moreover, excessive wages induce too much outsourcing of upstream production activities which implies that export quantities grow too much in relation to value added contained in exports. Finally, excessive wages cause capital flight resulting in a too large current account surplus.
\end{abstract}

JEL Code: E240, J650.

Keywords: trade, wage rigidity, replacement incomes, Germany.

Hans-Werner Sinn

Ifo Institute for Economic Research at the University of Munich

Poschingerstr. 5

81679 Munich

Germany

sinn@ifo.de

The World Economy Annual Lecture, Nottingham, October 2005 


\section{The Export Puzzle}

The German economy poses a puzzle. On the one hand, the country is vice champion in world exports after the US and even champion when services are disregarded and only commodities are considered. On the other hand it has been EU growth laggard in a number of recent years and "vice laggard" on average in the decade from 1995 to 2005 after Italy. German exporting companies are doing extremely well, the country has a huge current account surplus and the DAX is steadily moving up to previous highs, and yet the economy is stagnating and the labour market is limping. Mass unemployment has increased along a linear trend for 35 years and is currently at a record level. The resulting fiscal strain has caused Germany to violate the EU Stability and Growth Pact for four consecutive years with a budget deficit consistently above the $3 \%$ ceiling. Even economists have a hard time understanding how all of this fits together.

Most economists and politicians argue that Germany is obviously able to realize gains from trade and successfully react to the forces of globalization, but needs to solve its internal problems. There are different opinions, however, about the nature of the internal problems. A majority of economists believe that the country's labour market is too rigid and wages of the unskilled are too high for a sufficient number of jobs to be created, but do not relate this problem to international economic conditions. A minority of economists and a sizeable group of politicians and journalists argue that the poor performance of the domestic sectors results from a lack of domestic demand that could be overcome by Keynesian deficit spending.

This paper offers a different explanation. Export boom and weak domestic growth are not separate events, but are economically closely fitting parts of a 
development process which is caused by labour market rigidities. International lowwage competition of the Asian and ex-communist countries defines a new labour market equilibrium with lower wages, but unions as well as the fixed replacement incomes provided by the welfare state prevent domestic wages from adjusting. The economy reacts by moving from labour intensive to capital intensive sectors, by investing capital abroad and by replacing manpower by machine power. These reactions cause high exports, a large export surplus and mass unemployment at the same time.

\section{Reactions to Excessive Wages}

Like so many other western economies, the German economy has to struggle with world wide low-wage competition that has gained enormous strength during the last few decades. In the 1960s came the Japanese, in the 1970s and 1980s the Asian Tigers, and in the 1990s the ex-communist countries, from Poland to China, comprising no less than $28 \%$ of the world's population, and now also India is on the move with another $12 \%$. While the new competition has confronted all countries of the West with serious adjustment problems, Germany has been affected particularly strongly because of its high wages.

During the last two decades West Germany had the highest hourly wage cost of industrial workers in the world, and only recently has it been surpassed by Denmark. In 2004 West German wage costs per hour for industrial workers stood at 27.60 euros while the respective costs for Sweden, France, the US, Japan and Britain, to name only five comparable countries were 23.30, 20.70, 18.80, 17.90 and 19.90 euros respectively. Figure 1 provides an overview of the current situation. 


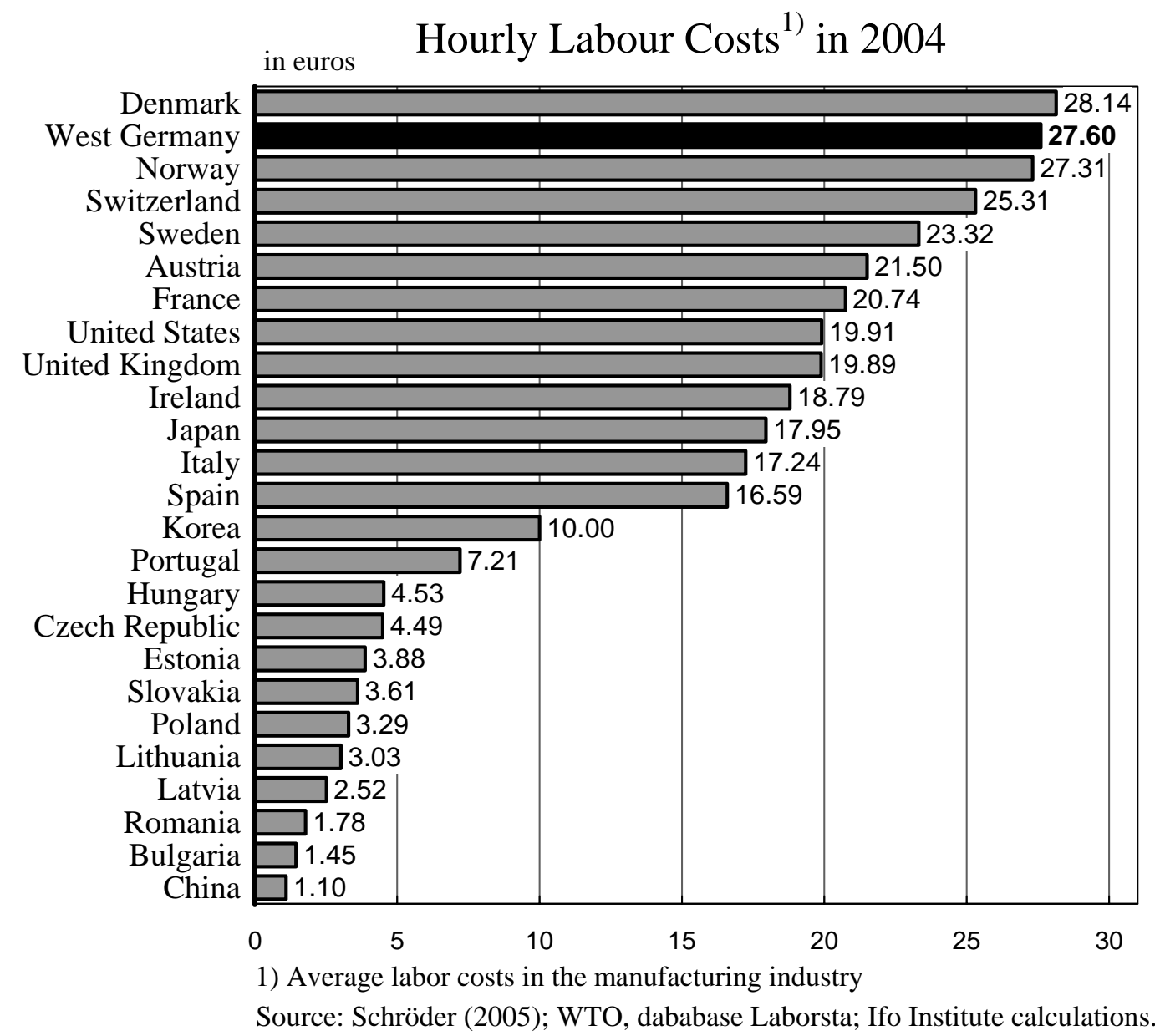

Figure 1

The high wage costs have induced various flight reactions of German firms and wealth owners. Since the 1970s and 1980s, firms have been fleeing to robots. This was the period when workers were crowded out from their firms at an increasing speed and when factories became workplaces for robots instead of people. Capital deepening was the natural reaction of competitive firms.

Since the Iron Curtain has come down and the ex-communist countries have overcome their transformation crises, firms have also been fleeing to the Poles and the Chinese. The average hourly wage cost of the ten new EU accession countries is less 
than 4 euros or just about $13 \%$ of the west German wage cost. In China, wage costs are less than one euro.

The fierce international competition with low-wage products and low-wage locations has reduced the scope for profitable investment in Germany. As shown in Figure 2, at a value of less than 3\%, Germany's net investment share in net national product (NNP) was the lowest among all OECD countries in 2004. Instead of investing in Germany, the Germans exported capital in the amount of 4.6 percent of NNP in 2005. Currently, net investment abroad is $50 \%$ higher than domestic net investment. German firms are currently engaged in an "investment strike” to use the Marxian term. 


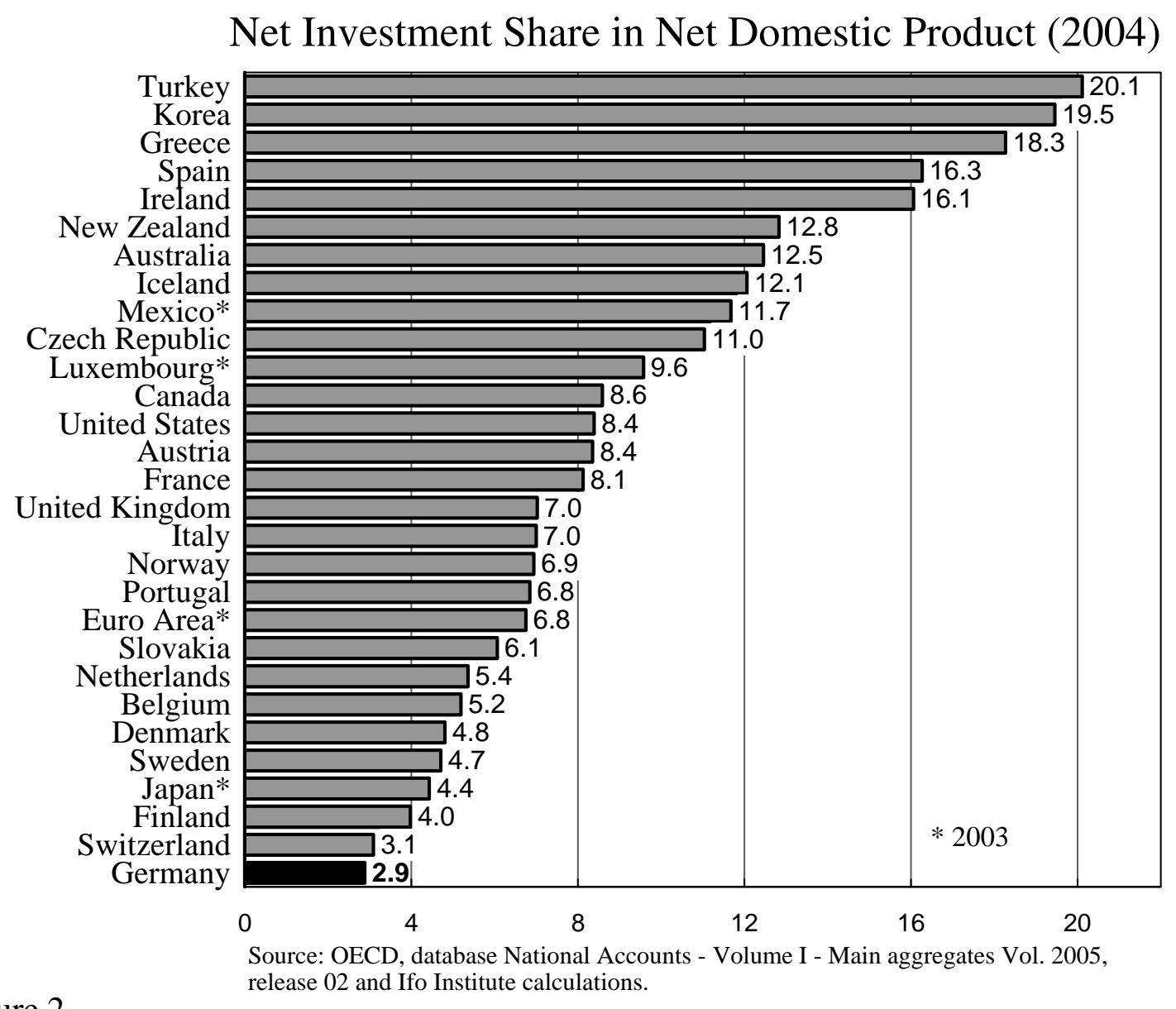

Figure 2 release 02 and Ifo Institute calculations.

Many firms are giving up, closing down or downsizing their plants, yielding to their foreign competitors without a fight. Many are declaring bankruptcy. At close to 40,000 cases per year, the number of bankruptcies was at a post-war record level in 2005. The savings capital no longer needed by these firms is moving abroad, which explains a substantial part of capital exports.

But the majority of firms adjust and survive by replacing men by machines and having their products prefabricated abroad. By outsourcing and offshoring, i.e. by purchasing intermediate products from foreign suppliers and setting up their own manufacturing plants abroad, they make use of the low-wage regions that were created 
by the collapse of communism. The small and medium size enterprises (SME's) are repeating in eastern Europe what the big companies have done in Asia since the 1980s. They globalise in the small. By averaging out domestic wage costs with those at locations in eastern Europe, they succeed in meeting the competition from Europe and Asia. The higher the wages, the more the weights of the average wage are shifted east, and this is how the companies survive.

According to a survey by the Cologne Institute for Business Research (IW, 2002), close to 60 percent of the SME's with 1000 to 5000 employees had already established plants outside the old EU by 2002, and, according to the direct investment statistics of the Deutsche Bundesbank (2004), German firms had created 3.5 million jobs abroad, if weighted with ownership shares. Germany is the biggest direct investor in eastern Europe, bigger than the United States and bigger than the United Kingdom and France combined. Direct investment in eastern Europe has been growing extremely fast in recent years. By now the number of jobs that German firms have created in eastern Europe amounts to between 800.000 and 1 million, about equal to the total of jobs they created in the United States over the last few decades.

\section{The Bazaar Economy}

The customers of the German firms are often unaware of the relocation. While labour intensive upstream activities are shifted abroad, the downstream stages of production remain in Germany and are even expanded. Instead of "Made in Germany“, "Designed, assembled and sold in Germany” would often be a more appropriate label, and even that may in part be an exaggeration. Take the Porsche Cayenne as an example. That car is seemingly produced in Leipzig, but in truth the assembly line is located in Bratislava, 
Slovakia. Little more than the engine is added in Leipzig. According to a study by Dudenhöffer (2005), only about a third of the production value of that car is generated in Germany. No wonder then that Porsche has no problems with German wage costs.

Figure 3 reveals that the production depth of German manufacturing has declined very rapidly in the last three decades, more than in other countries. In fact, it has fallen from above the respective averages of France, Japan, the UK and the US in the early 1990s well below these averages since the end of the 1990s. Germany is no exception from the other members of the old EU. Similar trends are observable in many countries. However, as the figure shows, the trend is more pronounced in Germany than elsewhere, notwithstanding the fact that the manufacturing sectors of smaller countries by the very nature of being small have always had to rely more on imported intermediate products than Germany. 


\section{Bazaar Effect in International Comparison}

Share of own value-added in manufacturing output

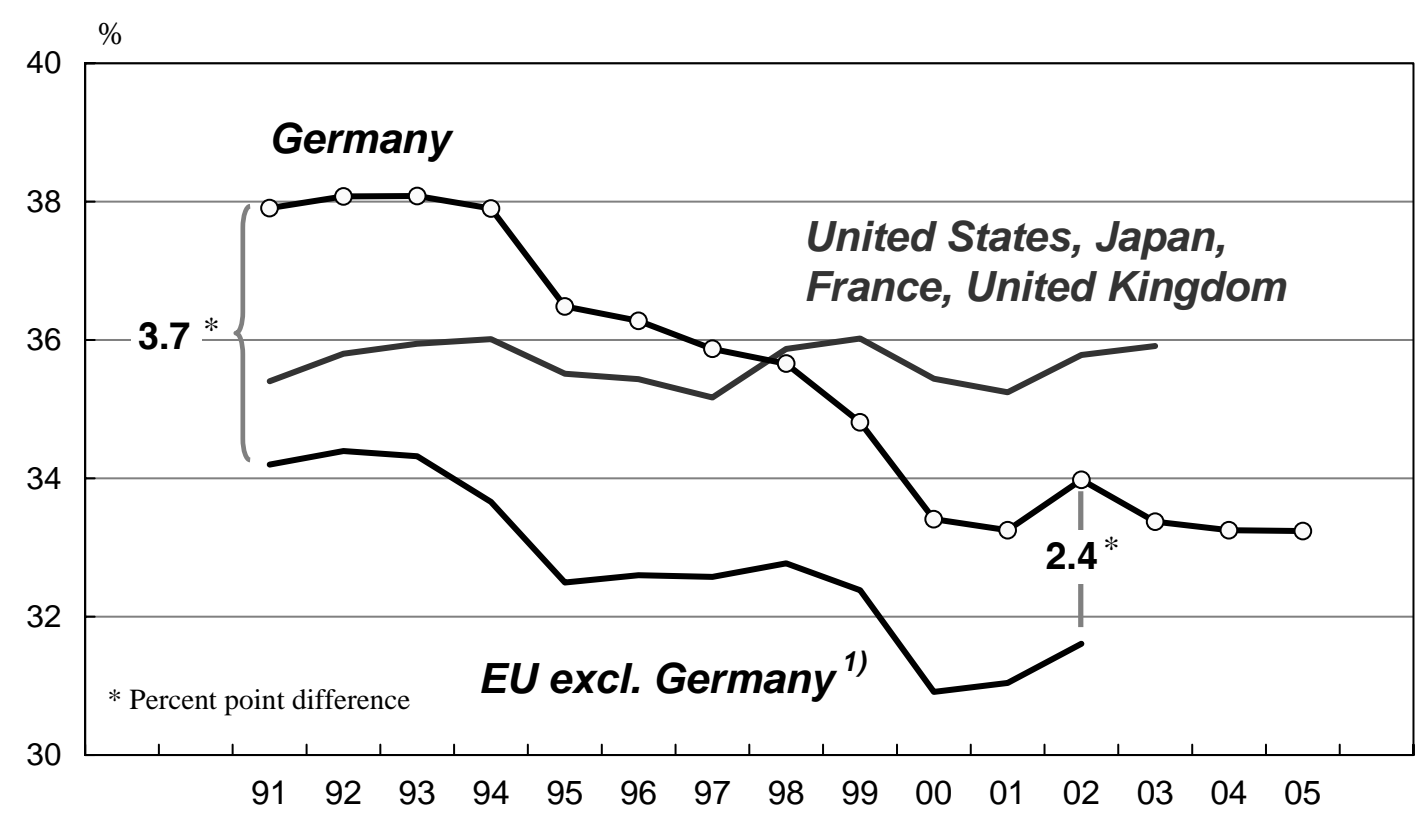

1) Belgium, Denmark, Finland, France, Ireland, Italy, Luxembourg, Netherlands, Austria, Portugal, Sweden, Spain and United Kingdom.

Sources: German Statistical Office, Special series 18, Series 1.4, OECD, STAN database for Industrial Analysis, Deutsche Bundesbank, Ifo Institute calculations.

Figure 3

It has been suspected that the decline in production depth has no external causes but results primarily from shifting value added from the manufacturing to the service sector, for example by large scale industrial leasing arrangements. However, this suspicion is clearly not true. As Figure 4 reveals, intermediate products delivered from other domestic sectors to the manufacturing sector have increased only a little more since 1995 than the production value of that sector itself. The main reason why value added in manufacturing fell behind manufacturing output is the enormous increase of imported intermediate products, no less than $64 \%$ over a period of nine years in real terms. Nine tenth of the decline in production depth of the German manufacturing 
sector in the period from 1995 to 2004 has resulted from shifting intermediary production abroad, and only one tenth has resulted from shifting it to other countries.

\section{What Determines the Reduction in Manufacturing Depth?}

(manufacturing industry) from 1991 to $2004,1995=100$

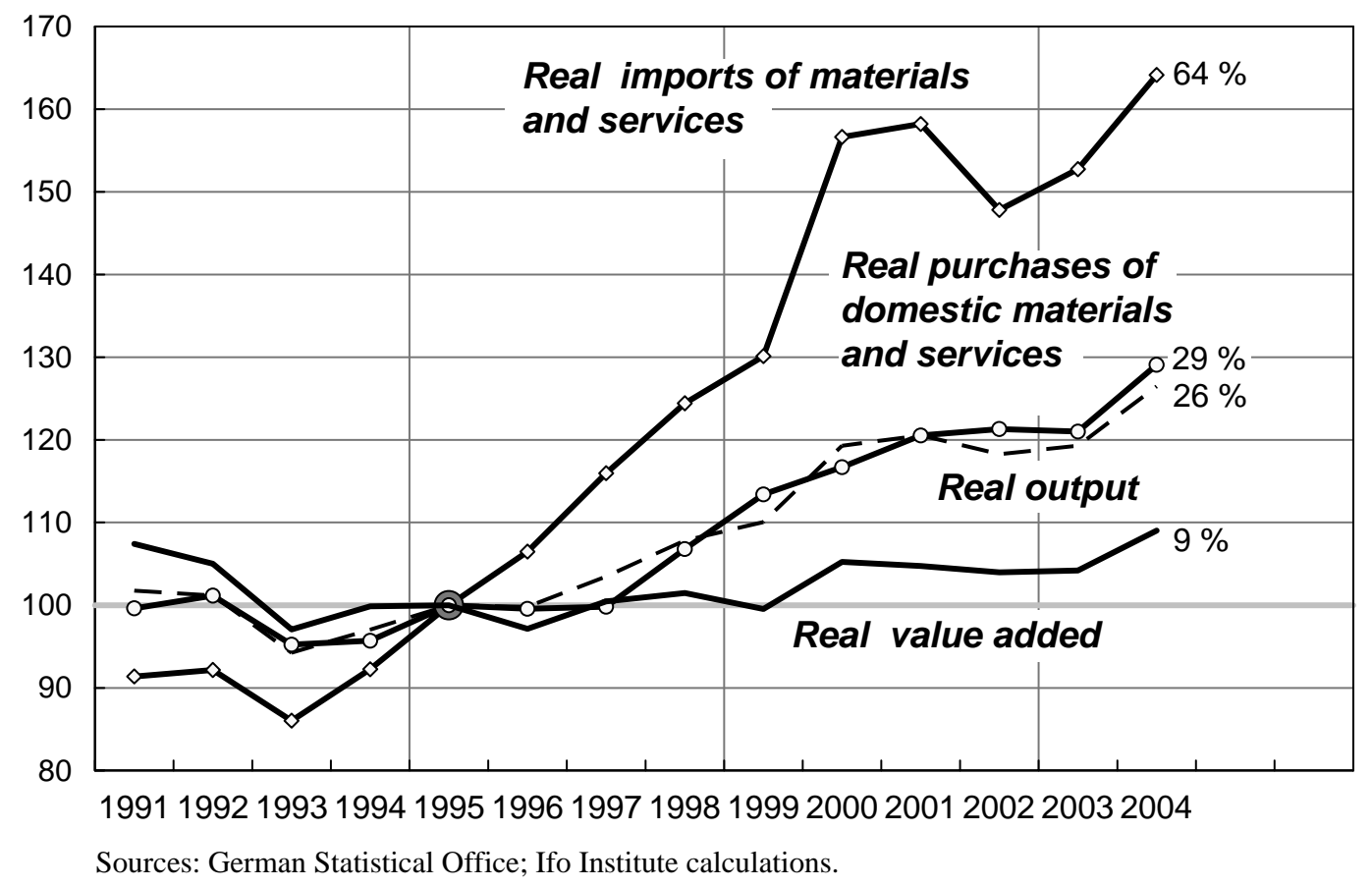

Figure 4

Germany is gradually turning into a bazaar economy that is supplying the world with a broad range of products but has a growing share of the value of its goods produced in its east European hinterland. The average import share in German exports has increased from 27\% in 1991 to 39\% in 2002 (Statistisches Bundesamt 2004, p. 4), and at the margin the import content of exports is already 53\%. Of each additional euro of revenue a German exporter collects, he needs 53 cents to buy the imports necessary for the production of his exports (Sinn 2005, p. 112). German firms are reducing their 
production depth at a rapid pace. The obvious implication is that more and more goods are channelled through the country relative to the value added produced in exports.

In a sense, this development is not new. In fact, the German economy has been the world`s bazaar economy ${ }^{1}$ for a long period of time. There is hardly another country offering the world a similarly wide range of sophisticated manufacturing products. German engineering and its dual education system are still the main reasons for the world championship in merchandise exports. Germany has 450 SMEs that are world leaders in their market niches, it is the country of the silent stars. Germany also is the country of the big industry fairs, at which everyone who wants to be someone has to present his products. Fifteen out of the twenty biggest trade fairs of the world, if measured by the in-house exhibition space, take place in Germany. Only five take place outside this country.

What is new is that the bazaar is relocating its workbench. Before the Iron Curtain had come down, it was clear that the industrial goods sold over the German counter were produced on a workbench in the backyard. Now, with the low-wage production sites in the East, an increasing fraction of the work benches is moving abroad, while the counter remains in Germany. This does not mean that value added in exports is declining, as the number of counters may also be increasing. However it does mean that trading volumes increase faster than value added.

In principle, the specialisation on bazaar activities can be expected to bring about gains from trade for Germany. In the final stages of the production chains, in which Germany has specialised, not only assembly jobs are created, but primarily

1 The term "bazaar economy" has been introduced by Sinn (2003b); for a comprehensive description of Germany as a bazaar economy see Sinn (2003a, pp. 71-77). 
sophisticated jobs in designing, engineering, marketing and all the other services concerned with the distribution of products. Germany can further expand its role as the nerve centre of European trade, as the bridge between east and west, and can thus complement its traditional role as manufacturer for the world.

Many argue that the Germans should really feel lucky that the Poles and Chinese do the industrial dirty work for them and that they can employ the industrial workers released in the upstream stages in the downstream stages, in the service industries, in construction and in high-tech areas. By relocating valuable human labour to more sophisticated activities, which they do not want to leave to the Chinese and Poles, gains from trade are created for Germany. The production of the Cayenne in Bratislava is no problem for Germany but an advantage: Without Bratislava no Leipzig!

\section{Division of Labour à l'Allemande}

This picture is too good to be true. There is something wrong with it. How can the country be at the bottom of the growth league if it benefits so much from the relocation of jobs, and why the horror reports about the labour market that cause so much uneasiness throughout the country?

The theory of structural change is wrong. The industry workers replaced by Chinese and Poles are not released for more valuable jobs, but for nothing at all. The official statistics on the number of jobs do not show this, however, for the many "minijobs”, “one-person firms”, and "one-euro jobs” for which policy has paved the way in recent years cloud the view of the real world. The statistics record 1.18 million additional jobs for the period 1995 to 2005. If part-time jobs are recalculated as full- 
time equivalents, two half-time jobs as one full-time job, for example, the picture clears up.

It becomes evident that Germany lost 1.21 million full-time equivalent manufacturing jobs from 1995 to 2005, a figure that already incorporates the creation of additional jobs in the new downstream stages of production à la Leipzig ${ }^{2}$. This corresponds to half of the picture of efficient structural change.

Unfortunately, the other half of the picture does not fit. In the remainder of the economy, where the high-value jobs for the released industrial workers would have to be created, employment did not rise during the same period of time. The number of fulltime equivalent jobs even declined a bit $(150,000)$. Thus total German employment calculated in full-time equivalents fell by 1.36 million people during the past ten years.

The industrial workers, replaced by Chinese, Poles and all the other low-wage workers, did not move to higher-value jobs, where they would have earned higher incomes, but into leisure and the welfare state, surely also into the underground economy. There has been no improvement in the international division of labour as one would have expected on theoretical grounds.

Rather, German firms dismiss their workers without creating replacement jobs. Firms remain competitive, workers do not. Firms maintain their competitiveness for the very reason that they get rid of their German workers, replacing them by Romanians, Bulgarians, Hungarians, Chinese or robots. The ship stays afloat because it has thrown part of its crew overboard as ballast. This may be good for the owner of the ship and the

2 Ifo Institute calculations on the basis of Statistisches Bundesamt (2006) and Institut für Arbeitsmarktund Berufsforschung (2005, p. 8); data have been adjusted for varying numbers of working days.. 
rest of the crew that remains on board, but not for that part that, downgraded as ballast, sank to the bottom of the sea.

\section{Wage Convergence as Destiny}

The German public is watching all of this with bewilderment. The anger about the high profits of the DAX firms at the same time that there are mass dismissals, the abolition of banking secrecy and the demands for publication of manager salaries, the Social Democratic Party leader's criticism of locust capitalism are powerless reactions to a development that deeply hurts the Germans' sense of justice. One needs not be "equality-prone“, as a supreme court judge recently criticized the Germans, to understand these emotions.

But value judgments and ideas about morals do not lead anywhere, for they will not change the laws of economics that generate these developments. Among the laws of economics, it is primarily the law on factor price equalisation that is responsible for the German problems. Factor price equalisation says essentially that wages of trading partners at similar stages of development converge because capital movements and merchandise trade create in fact one single world labour market. If factor price equalisation is resisted, the unemployment results that is so lamented in Germany.

Factor price equalisation is not a spontaneous event. It is a slowly but surely proceeding economic tendency of an iron law of economics that will take generations to work its way through. Even under the optimistic assumption that sigma convergence is 2\% p.a., corresponding to a half life of 35 years, for closing the wage gap, hourly wage costs in the new EU countries will have risen from their current $13 \%$ to $50 \%$ of west German wage costs by 2030. If previous convergence experience in western Europe 
which suggests a convergence rate of about $1 \%$ is used for the forecast, $50 \%$ of west German wages will be reached only by about 2060 (Sinn and Ochel, 2003, p. 871; Egger and Pfaffermayr, 2006)..

Unfortunately, wage convergence as a rule moves in both directions. East European wages will rise faster than would have been the case in the absence of the collapse of the Iron Curtain, and German wages will rise less or even decline.

Germany can try to slow down factor price equalisation by increasing its innovation lead. After all, one can be as much more expensive as one remains better. A strengthening of basic research, promotion of innovation and improvement of education in schools and universities, these belong to the agenda of a rational policy. But the competitors are not stupid either, and technological knowledge that gives rise to productivity leads spreads quickly. Nobody can prevent inventors and entrepreneurs from exploiting their patents in Poland or China. There are ways to slow down factor price equalisation by becoming better, but they are limited.

If Germany tries, however, to slow down factor price equalisation by political power, be it the power of the unions or the power of the welfare state, mass unemployment will be the inevitable result.

\section{The Desperate Fight against Wage Convergence}

German workers were able to benefit greatly from the law of factor price equalisation in the immediate post-war period, when Germany was still prostate and was gradually being reintegrated into the world trading system. At that time, Germans were the lowwage workers who competed with other countries. Competing with well fed Americans 
was a good thing. Capitalism was fun, and there was no reason to resist the law of factor price equalisation. Many were able to enjoy the economic miracle.

The economic miracle faded in the 1970s, when Germany had already converged on the Americans and when the Japanese took over Germany's precision engineering and optical industries. Ill feelings spread when, in the 1980s, the many small Asian tigers emerged and not only killed the German textile industry but also bore down hard on Germany’s electronics and electrical industries.

Today, when Germany is dealing with factor price equalisation with the excommunist countries, whose people are vying with starvation wages for the internationally mobile capital, depression is setting in. China alone is ten times Japan. Germany cannot manage with the Chinese as easily as the Americans did with Germany at the time. Like their colleagues in other Western countries, German workers now belong to the losers of globalisation because wage competition is pushing their incomes down instead of pulling them up.

German policymakers resist factor price equalisation today with everything that is sacred to them. The unions are barricading themselves for the big defensive battle, the politicians are considering minimum wages, and the welfare state blocks the necessary downward wage adjustment with its wage replacement benefits. Because of past wages, the welfare state is offering comparatively high competing wages for doing nothing with unemployment pay, social assistance and early retirement options. The private sector cannot outbid these wages because of international low-wage competition and does no longer want to in view of its own options in the East. Squeezed between the high-wage competition of the German welfare state in the labour market and the low- 
wage competition in international product markets, German jobs are successively pushed out of the market system.

The wage blockage also blocks the new gains from trade, however, which Germany could extract from globalisation and a further specialisation of its production. Gains from trade and factor price equalisation always go hand in hand because gains from trade result from a country's specialisation in certain sectors and because specialisation only functions if flexible labour markets allow the movement of labour among sectors. You cannot have one without the other. That is why, as a rule, gains from trade are only possible in the sense that the winners win more than the losers lose. The pie becomes bigger, but some get an absolutely smaller piece. It is obvious that society does not accept this when the number of losers becomes big and well organised politically. That is the core of the German dilemma.

Because of rigid and high wages, the labour intensive sectors lose too many jobs, and other sectors create too few new jobs. Unemployment continues to rise, growth slows down, and in view of the financial consequences the welfare state faces a crisis. There is no trace of new gains from trade derived from eastern enlargement or globalisation.

Why the Export Boom does not Indicate Gains from Trade

Some may consider this is an exaggeration. German exporting world championship does not fit this bleak picture! The championship proves that Germany is competitive and is only suffering from domestic demand problems which can be mitigated with Keynesian policies. 
Unfortunately, this conclusion is ill founded. Firstly, because the evolution of the bazaar economy inflates the volume of export quantities relative to the value added contained in exports, secondly, because the export boom cannot be taken as an indicator of gains from trade, and thirdly because both of these effects are pathologically overdrawn. Let us look into this in detail.

The first effect is the bazaar effect. If a country, as Germany is doing, specialises in bazaar activities in the sense of downstream stages of production and lets more and more people work there, then with the expansion of value added in these stages it must import, piggyback, more and more intermediate products from abroad, which are immediately exported again after having being reprocessed. In 1991, 27\% of German exports consisted of imports of intermediate goods. By 2002 this figure had risen to 38\%. And the marginal effect is even larger. Of each euro that is spent on additional exports, 55 cents are already used for imports of intermediate products and of merchandise. And one percent of additional real export-induced value added results in a rise of the export volume by 1.36 percent. The German economy is becoming like a continuous-flow water heater for manufactured goods that, on their way from Slovakia to America, pass through the German statistics. This does not, in itself, imply that there is something wrong with this development. However it is an explanation for why exports are so high.

Note that a specialisation in upstream activities would not have decoupled value added in exports and export quantities. With no imported intermediate products both variables would have grown proportionately, and if the share of imported intermediate goods had declined, value added would have grown faster than export quantities. 
More important is the second effect. One must not ignore the fact that not only the export volume is rising, but so is the value added in exports themselves, i.e. what Germany adds before it exports its imports again, thereby creating income in Germany. Although the share of domestic value added per unit of exports is shrinking, the number of units is growing so fast that it more than offsets the bazaar effect with regard to aggregate value added. Value added in exports is rising more than GDP and the other income aggregates. An ever increasing share of income earned in Germany is generated by exports.

Many people think that this proves that Germany is managing quite well with globalisation and is achieving gains from trade. The number of those who think like that ranges from the German Council of Economic Experts to a majority of the media and the respective ministries of the Federal Government.

They are overlooking, however, that export goods are those goods in which a country specialises after trade is opened. By definition, specialisation means that labour and investment capital move into export production so that the income earned there, i.e. the value added, rises more than proportionally, and this holds also when the sectors in which a country specializes are downstream elements of the value added chain. It is true, therefore, for each normal country that participates in the expansion of trade that value added in export grows faster than average value added, that is faster than GDP.

Economic advantages for Germany cannot be derived from this observation for the simple reason that it merely describes a self-evident implication of specialisation. Labour and capital, which move to the export industries, originate in other sectors that must cut back their output and value added correspondingly. This reduction in value added must be subtracted before an assessment is possible. Therefore aggregate growth 
figures show better how a country is coping with international trade than export statistics. If the farmer sells more wheat because he uses less land for the production of rye, it does not follow either that he increases his profits by doing so.

\section{The Pathological Export Boom}

Let us now turn to the third effect. Economic advantages cannot be derived from the export boom because Germany has all but fled into exports because of the high-wage policy followed in past decades. Only at first sight does the country give the impression that it is coping well with globalisation. A country that fixes its wages above the internationally competitive level is forced to specialise excessively in capital intensive products at the expense of labour intensive products, because this is the only way in which it can survive foreign competition. This is the practical variant of a brief theoretical allusion made by Srinivasan (1995, p. 372) in a comment on Krugman (1995) and it also follows from the theory of foreign trade with fixed wages as developed by Brecher (1974) and Davis (1998).

Germany exports capital intensive goods and imports labour intensive goods. Capital intensive goods are those that are produced with a high input of sophisticated machinery and expensive plant but that require only few production workers. Examples are mass manufactures that are produced on automated assembly lines and require little labour. Human capital intensive goods that impose high demands on technological knowledge also can be taken to belong to this category. Let us, for the purpose of analysis, lump these two kinds of capital together and distinguish unskilled labour from them. Labour intensive goods are those for which unskilled human labour is most 
important. They range from textiles and clothing to personal services like haircuts or tourism.

In principle, German specialisation in capital intensive goods is to be expected from a healthy development of international trade because the country is capital rich in an international comparison. However, the high and increasing level of German unemployment shows that wages are above their market clearing level. With regard to the international division of labour this has had very unfavourable consequences. The high German wages have destroyed labour intensive production beyond a healthy extent and have forced the country to satisfy its needs by growing imports. Too much labour and capital were released by the labour intensive branches of industry. Financial capital set free be depreciation moved to other sectors and the increments of the economy's capital stock financed from savings did so, too. Land and real estate in general was used in other sectors and the skilled children of those people that used to be employed in the labour intensive sectors of the economy chose different occupations enabling them to work in the capital intensive high-tech areas of the economy. With them, of course, the unskilled moved to sectors where they could find jobs. The released factors of production pushed into the capital intensive export sectors that were still best able to deal with the high wages (for unskilled labour). These sectors expanded beyond their efficient size providing the goods necessary to purchase imports. That is why exportinduced value added is booming in Germany.

But the boom has pathological characteristics because the capital intensive sectors were able to absorb the capital but not the many unskilled who were dismissed by the labour intensive sectors. Unemployment has been rising, and as the jobless do not create value, growth has slowed down. 
Possibly, the extension of trade will not even bring about additional gains from trade for Germany. This must be feared if wage stickiness leads to such an excessive expansion of trade that Germany's terms of trade cannot improve. Gains from trade will rise only if the terms of trade move further away from their autarky values. When there are no changes in the terms of trade while unemployment rises, additional gains from trade are impossible because the economy operates below its production possibility frontier.

With competitive wage determination, which would have resulted in lower wages, things would have been different. With lower wages, large parts of labour intensive industries would have survived, and at the same time, all industries would have been induced to choose less capital intensive production processes, i.e. would have employed more people instead of machines. Unemployment would have been avoided for both of these reasons.

The most important aspect of an efficient market reaction with declining wages would be the larger survival rate among the labour intensive industries. It implies that less capital would have been sent to the capital intensive export sectors, and with it also less labour would have had to move to that sector. Value added in the export sector would have been smaller, but value added in the labour intensive sectors would have been larger. In fact, even aggregate value added would have been higher as less labour would have remained idle. Measured against the yardstick of a competitive economy, the size of the export sector in the German case of fixed wages that are above the market clearing level is excessive. Germany is experiencing a pathological export boom.

Among the labour intensive industries that have been replaced by imports in Germany are textiles, leather as well as precision instruments. They no longer play an 
important role as employers. Above all, however, home and restaurant services have been lost that used to employ a substantial number of Germans.

Former president Roman Herzog thought that Germans are not producing services because they do not like to serve. But there has not always been a lack of willingness. That it is lacking today is the result of the high-wage policy of the unions and the wage competition of the welfare state. Germans have become too expensive to be willing to purchase services from one another.

They switch instead to purchases of manufactured goods and foreign services. The cleaning lady is a self-employed worker from Poland, and leisure is sought in Mallorca. In the midst of its economic lull, in 2004, Germany became world merchandise exporting champion and world tourism importing champion at the same time.

Why the Bazaar Effect is Overdrawn

In the model of Brecher and Davis, which basically is a mutant of the Heckscher-Ohlin model, the economic sectors among which excessive factor movements take place, are vertically integrated production chains like those defined in national accounting systems. However, today, capital movements also occur between sectors defined as stages in vertical production chains. Downstream activities are generally more capital intensive than upstream activities where manual labour still plays an important role.

For one thing, downstream activities typically involve much inventory capital per worker because intermediate products are used that have already passed many production steps and are accordingly expensive. This is the basic view of BöhmBawerk’s (1889) temporal theory of production, the predecessor of neoclassical capital 
theory. Capital is basically inventory capital, and the more of this capital is used per unit of labour, the bigger the number of production steps the inventories have passed already. Secondly, downstream activities often require much human capital in terms of design, marketing and engineering skills, because the final products are developed and customised in downstream facilities and the upstream activities have to subject themselves to this definition.

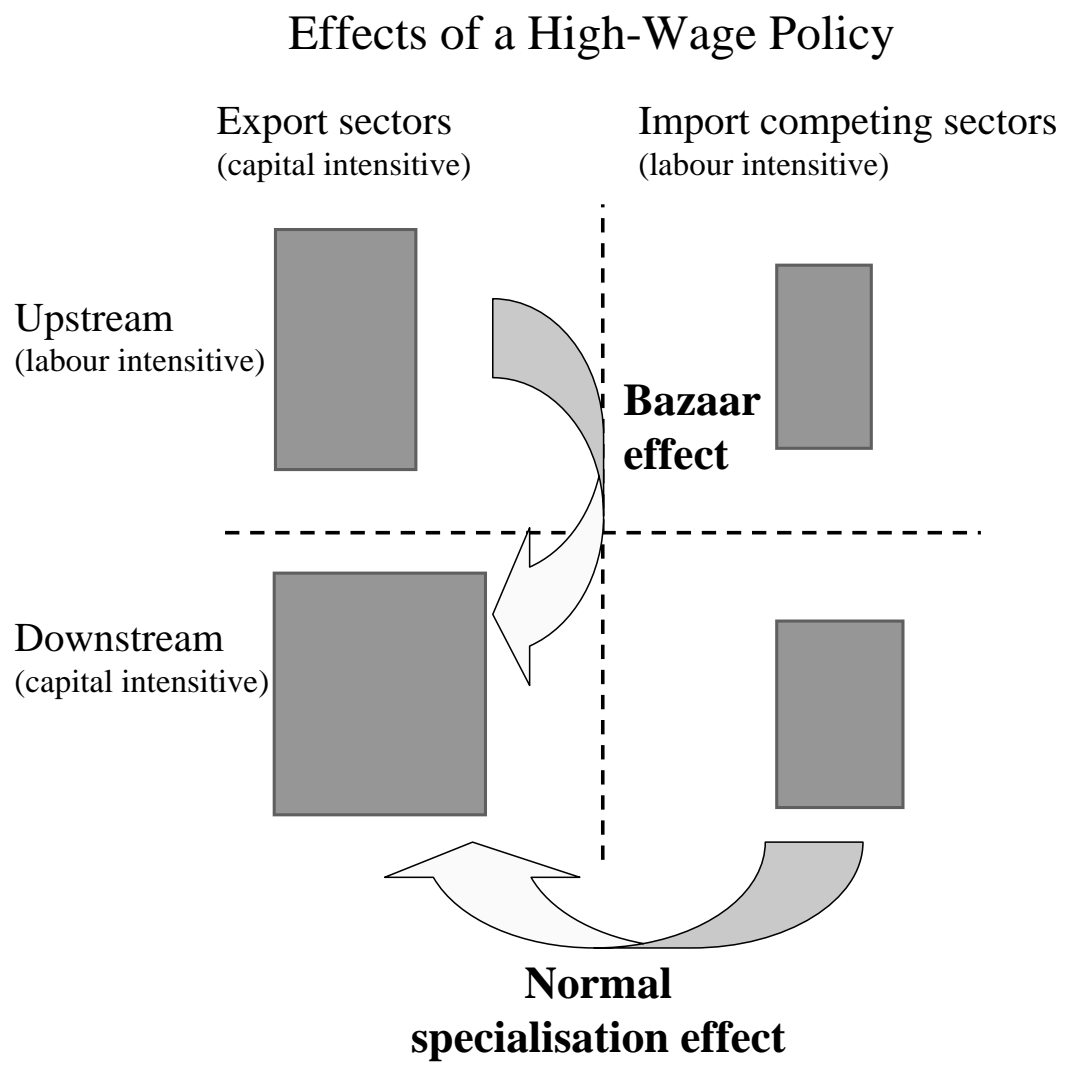

Figure 5

Figure 5 explains the direction of specialisation in a simplified model with two vertical production lines, each of which consists of two stages of production. The normal specialisation effect is horizontal and goes from labour intensive to capital intensive production lines. The bazaar effect is vertical and goes from upstream to 
downstream activities because the latter are the more capital intensive ones. As a result of both specialisation effects, economic activities are concentrated in the downstream sectors of the capital intensive production lines.

In principle, both the horizontal specialisation and the bazaar effect are efficient reactions to the new trade relationships with labour abundant countries. However, as explained above, high and rigid German wages that have failed to react to the forces of globalisation and international low-wage competition have induced excessive factor movements that go beyond the social optimum and induce unemployment. In particular, high and rigid German wages have induced excessive factor movements from upstream to downstream activities. The Brecher-Davis-Srinivasan effect has artificially reinforced the bazaar effect expanding even further the volume of German exports beyond the export-induced value added. The above mentioned elasticity of the export volume with respect to the export-induced value added of 1.36 is partly the result of this distortion. It is true that the efficient level of this elasticity would also have been above unity due to the normal specialisation effect, but the bazaar effect would have been weaker and the numerical value of the elasticity would have been smaller had wages adjusted so as to avoid unemployment.

To summarize, there have been two pathological forces in German trade. For one thing, value added in exports grew too quickly, and for another the bazaar effect was too strong which meant that export quantities grew too quickly relative to export value added. Both effects together resulted in excessive export growth. The export boom combined with increasing unemployment and stagnation in the rest of the economy are the normal symptoms of a high-wage country that is unable to exploit globalisation to its own advantage. That is the sad solution of the German puzzle. 


\section{But the Trade Surplus!}

Some readers may still refuse to accept this explanation by pointing to the German trade surplus. As exports are still rising even if offset by imports, Germany appears to be a winner of globalisation at this very time. But this mercantilist view is clearly not correct.

A country can only give away or lend its export surplus. The foreign exchange that it earns but does not spend on imports, is partly given away as foreign aid, EU contributions or other unilateral transfers. The majority is invested abroad. Net exports are identical to net capital outflows.

One of Germany's problems is that its investors are no longer willing to use the growing domestic savings to finance domestic investment projects. The surplus of savings over investment is exported to other countries via the international capital markets. At the same time, the surplus of savings over investment is the surplus of the not consumed part of national output over investment that is moving abroad. Capital flight needs an export surplus to take place. If only for this reason, the export surplus cannot be interpreted as gains from trade.

Figure 6 shows how large the German export surplus in terms of the current account surplus (exports - imports - net transfers to other countries) has recently become. The figure suggests that the increase of the surplus can partly be attributed to the investment strike that was mentioned above (see Figure 2).

In fact, the current account surplus completes the pathological export boom as described above. The huge and artificially maintained gap between German and foreign wages for simple labour has pushed out more of the existing and potential capital from 
the labour intensive sectors of the economy than was efficient. Some of this capital moved to the capital intensive sectors of the economy, some fled abroad. Record levels of exports and the export surplus have resulted.

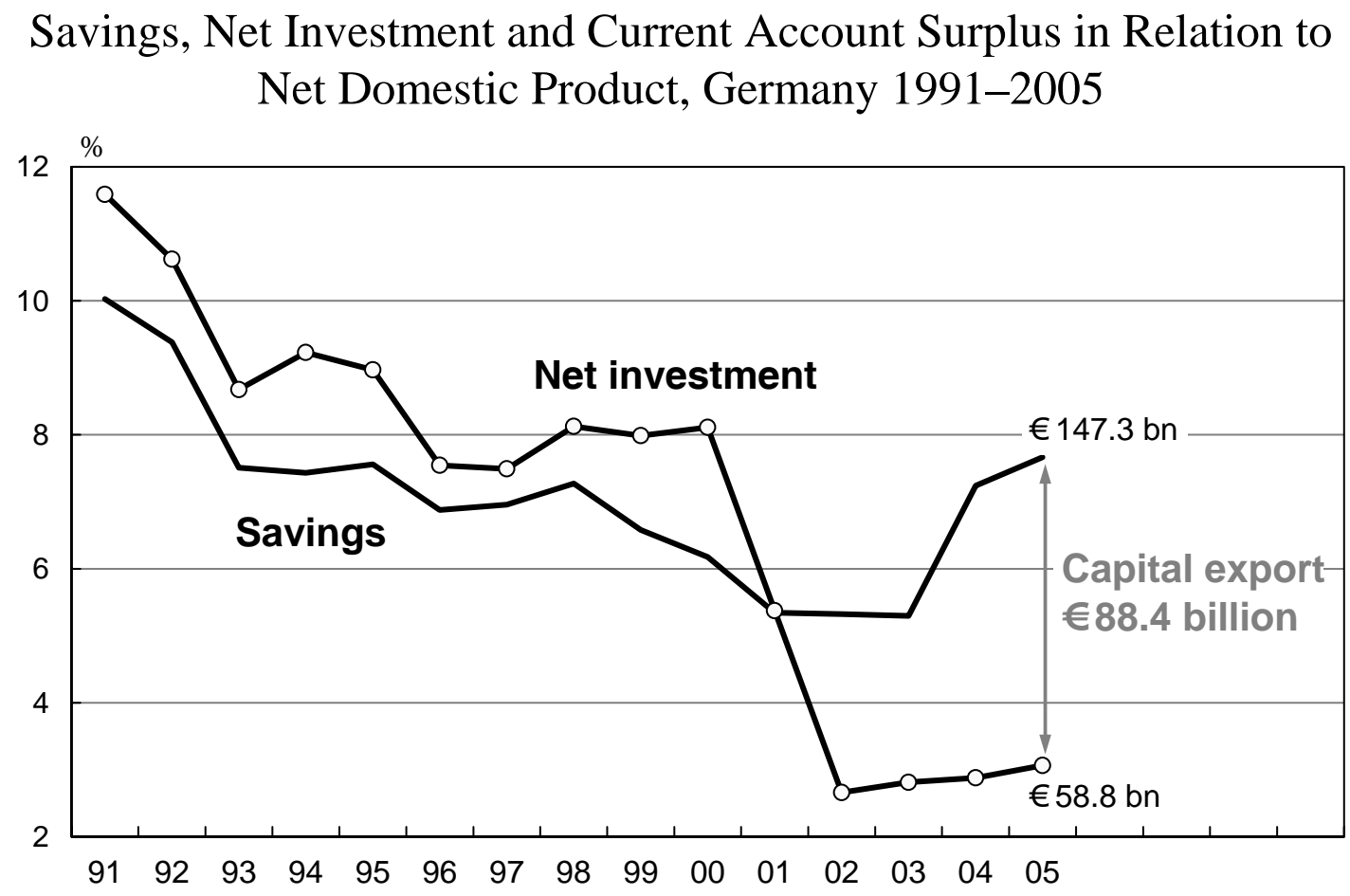

Sources: German Statistical Office, Special Series 18, Series 1.2, S.21 and S.26; Ifo Institute calculations.

Figure 6

An export of capital is not, of course, in itself a source of welfare losses. It could be part of an intertemporal exchange of resources that increases the welfare of all participating countries. However, to the extent the capital flight is induced by wages that are fixed above the market clearing level, such a favourable interpretation is not possible. As the technological factor input ratios are given in this case, a net capital 
export is a measure of the relocation of jobs abroad. The savings which are not invested in Germany are lost to the domestic labour market.

This pessimistic view may be countered by pointing to Germany’s favourable direct investment statistics. Recently, foreign companies have invested more in Germany than Germans have invested abroad. Does this not prove that Germany is importing capital despite the positive trade surplus? It does not. For one thing, direct investment is extremely volatile. One year the net flows go in this direction, next year it can be the other way round. For another, direct investment is only a small part of international capital flows. Net capital outflows, measured as the difference between exports and imports, already contain net direct investment abroad. Financial capital moving via the banks accounts for the lion's share of international capital flows.

Incidentally, direct investment does not measure what is commonly thought. In part, it includes the purchase of existing firms, for example the sale of the German pharmaceutical industry to the French. Above all, it includes the retained earnings of foreign firms located in Germany, for whatever purpose the retentions are made. If IBM Germany does not send its profits to headquarters, but invests them in the international capital market and in this way finances bank loans for a factory in Finland, this is counted as direct investment in Germany.

\section{What Is there to Do?}

In this historical phase, Germany cannot use the forces of globalisation to generate additional gains from trade because it holds on to wage structures that go back to the time before the ex-communist countries participated in international trade. Germany 
cannot continue with this strategy for any length of time because it leads to mass unemployment and chaos. What are the consequences for politics?

It would be fatal it politicians would conclude that they must weaken the forces of globalisation by new trade protectionism in order to reduce the pressure on German wages in this way. New protectionism would also put the past gains from trade at risk to which Germany essentially owes its prosperity to this very day. One cannot warn enough against this strategy. Those who demand tariffs and claim that this is not protectionism, do not know what they are talking about.

It would be just as fatal if the politicians were to introduce minimum wages. A policy of expanding the foreign posting law and declaring union wages as generally binding would prevent gains from trade, increase unemployment and prolong the ailing of the German economy. It would further accelerate the march along the wrong road that Germany has travelled for decades and that has led to the economic problems of the country.

Correct would be the promotion of education in order to improve the quality of the work force. But this will only help in the long term.

The only policy reaction that promises success in the medium term is making the labour markets more flexible combined with a policy of compensating the losers of the required wage adjustments. There is simply no alternative.

The unskilled, who lose the most, should be compensated with personal wage subsidies. The Ifo model of activating social assistance, which was recommended by the German President and which would replace state wage replacement benefits (and therefore would not cost any additional money), points to the right way. 
In addition, all employees should be able to participate in the gains from trade and redistribution accruing to the firms that result from factor price equalisation. The models of employee participation in their firms are well developed and functioning. The bargaining parties should increasingly agree savings wages instead of cash wages. If, at the same time, the already employed workers are distinguished from newly hired workers in this, the distribution conflict caused by globalisation will be defused and employment will be raised.

Germany can achieve its distribution goals only with and never against the laws of the market. Political power cannot cancel economic laws, especially not the law of factor price equalisation. If the Germans were to think a bit more Marxist in this respect, they would already get a lot closer to the solution of their problems. 


\section{References}

Brecher, R.A. (1974), “Minimum Wage Rates and the Pure Theory of International Trade,” The Quarterly Journal of Economics 88, 98-116.

Böhm-Bawerk, E. von (1889), Kapital und Kapitalzins, 2 volumes, Verlag der Wagner’schen Universitätsbuchhandlung: Innsbruck.

Davis, D.R. (1998), “Does European Unemployment Prop up American Wages? National Labor Markets and Global Trade,“ American Economic Review 88, 478-494.

Deutsche Bundesbank (2004), Kapitalverflechtung mit dem Ausland, Statistische Sonderveröffentlichung 10.

Dudenhöffer, F. (2005), „Wie viel Deutschland steckt im Porsche?“ ifo Schnelldienst 58, No. 24, 3-5.

Egger, P., and M. Pfaffermayr (2006), “Spatial Convergence,” Papers in Regional Science, being printed..

Institut der deutschen Wirtschaft (2002), IW-Trends, Dokumentation 4.

Krugman, P. (1995), “Growing World Trade: Causes and Consequence,” Brookings Papers on Economic Activity 1, 327-377.

Schöder, Chr. (2005); Industrielle Arbeitskosten im internationalen Vergleich, IWTrends 32, No. 3, 1-13.

Sinn, H.-W., and W. Ochel (2003), "Social Union, Convergence and Migration,” Journal of Common Market Studies 41, 869-896.

Sinn, H.-W. (2003a), Ist Deutschland noch zu retten? Econ: Munich. 
Sinn, H.-W. (2003b), The Sick Man of Europe: A Desk Socialist’s Diagnosis and Therapy, “The German Speech“ presented at Neuhardenberg (Neuhardenberg Palace Foundation). Live transmission by DeutschlandRadio Berlin on 15 November 2003, Ifo Institute for Economic Research: Munich. Printed and audio versions accessible through http://www.cesifo-group.de/link/_spezial/sinn-deutscherede112003.htm

Sinn, H.-W. (2005), Die Basar-Ökonomie Deutschland: Exportweltmeister oder Schlusslicht?, Ullstein: Munich, Berlin.

Srinivasan, T. N. (1995), Comments and Discussion on “Growing World Trade: Causes and Consequence”, Brookings Papers on Economic Activity 1, 368-373.

Statistisches Bundesamt (2004), Volkswirtschaftliche Gesamtrechnungen. Input-OutputRechnung. Importabhängigkeit der deutschen Exporte 1991, 1995, 2000 und 2002, Wiesbaden.

Statistisches Bundesamt (2006): Volkswirtschaftliche Gesamtrechnungen.

Inlandsproduktsberechnung. Detaillierte Jahresergebnisse 2005.

Fachserie 18/Reihe 1.4, Status: Februar 2006.

Institut für Arbeitsmarkt- und Berufsforschung (2005), Arbeitsmarkt 2005:

Zwischenbilanz und Perspektiven, IAB Kurzbericht 10. 


\section{CESifo Working Paper Series}

(for full list see www.cesifo-group.de)

1645 Burkhard Heer and Bernd Suessmuth, The Savings-Inflation Puzzle, January 2006

1646 J. Stephen Ferris, Soo-Bin Park and Stanley L. Winer, Political Competition and Convergence to Fundamentals: With Application to the Political Business Cycle and the Size of Government, January 2006

$1647 \mathrm{Yu}-\mathrm{Fu}$ Chen, Michael Funke and Kadri Männasoo, Extracting Leading Indicators of Bank Fragility from Market Prices - Estonia Focus, January 2006

1648 Panu Poutvaara, On Human Capital Formation with Exit Options: Comment and New Results, January 2006

1649 Anders Forslund, Nils Gottfries and Andreas Westermark, Real and Nominal Wage Adjustment in Open Economies, January 2006

1650 M. Hashem Pesaran, Davide Pettenuzzo and Allan G. Timmermann, Learning, Structural Instability and Present Value Calculations, January 2006

1651 Markku Lanne and Helmut Luetkepohl, Structural Vector Autoregressions with Nonnormal Residuals, January 2006

1652 Helge Berger, Jakob de Haan and Jan-Egbert Sturm, Does Money Matter in the ECB Strategy? New Evidence Based on ECB Communication, January 2006

1653 Axel Dreher and Friedrich Schneider, Corruption and the Shadow Economy: An Empirical Analysis, January 2006

1654 Stefan Brandauer and Florian Englmaier, A Model of Strategic Delegation in Contests between Groups, January 2006

1655 Jan Zápal and Ondřej Schneider, What are their Words Worth? Political Plans and Economic Pains of Fiscal Consolidations in New EU Member States, January 2006

1656 Thiess Buettner, Sebastian Hauptmeier and Robert Schwager, Efficient Revenue Sharing and Upper Level Governments: Theory and Application to Germany, January 2006

1657 Daniel Haile, Abdolkarim Sadrieh and Harrie A. A. Verbon, Cross-Racial Envy and Underinvestment in South Africa, February 2006

1658 Frode Meland and Odd Rune Straume, Outsourcing in Contests, February 2006

1659 M. Hashem Pesaran and Ron Smith, Macroeconometric Modelling with a Global Perspective, February 2006 
1660 Alexander F. Wagner and Friedrich Schneider, Satisfaction with Democracy and the Environment in Western Europe - a Panel Analysis, February 2006

1661 Ben J. Heijdra and Jenny E. Ligthart, Fiscal Policy, Monopolistic Competition, and Finite Lives, February 2006

1662 Ludger Woessmann, Public-Private Partnership and Schooling Outcomes across Countries, February 2006

1663 Topi Miettinen and Panu Poutvaara, Political Parties and Network Formation, February 2006

1664 Alessandro Cigno and Annalisa Luporini, Optimal Policy Towards Families with Different Amounts of Social Capital, in the Presence of Asymmetric Information and Stochastic Fertility, February 2006

1665 Samuel Muehlemann and Stefan C. Wolter, Regional Effects on Employer Provided Training: Evidence from Apprenticeship Training in Switzerland, February 2006

1666 Laszlo Goerke, Bureaucratic Corruption and Profit Tax Evasion, February 2006

1667 Ivo J. M. Arnold and Jan J. G. Lemmen, Inflation Expectations and Inflation Uncertainty in the Eurozone: Evidence from Survey Data, February 2006

1668 Hans Gersbach and Hans Haller, Voice and Bargaining Power, February 2006

1669 Françoise Forges and Frédéric Koessler, Long Persuasion Games, February 2006

1670 Florian Englmaier and Markus Reisinger, Information, Coordination, and the Industrialization of Countries, February 2006

1671 Hendrik Hakenes and Andreas Irmen, Something out of Nothing? Neoclassical Growth and the 'Trivial' Steady State, February 2006

1672 Torsten Persson and Guido Tabellini, Democracy and Development: The Devil in the Details, February 2006

1673 Michael Rauber and Heinrich W. Ursprung, Evaluation of Researchers: A Life Cycle Analysis of German Academic Economists, February 2006

1674 Ernesto Reuben and Frans van Winden, Reciprocity and Emotions when Reciprocators Know each other, February 2006

1675 Assar Lindbeck and Mats Persson, A Model of Income Insurance and Social Norms, February 2006

1676 Horst Raff, Michael Ryan and Frank Staehler, Asset Ownership and Foreign-Market Entry, February 2006 
1677 Miguel Portela, Rob Alessie and Coen Teulings, Measurement Error in Education and Growth Regressions, February 2006

1678 Andreas Haufler, Alexander Klemm and Guttorm Schjelderup, Globalisation and the Mix of Wage and Profit Taxes, February 2006

1679 Kurt R. Brekke and Lars Sørgard, Public versus Private Health Care in a National Health Service, March 2006

1680 Dominik Grafenhofer, Christian Jaag, Christian Keuschnigg and Mirela Keuschnigg, Probabilistic Aging, March 2006

1681 Wladimir Raymond, Pierre Mohnen, Franz Palm and Sybrand Schim van der Loeff, Persistence of Innovation in Dutch Manufacturing: Is it Spurious?, March 2006

1682 Andrea Colciago, V. Anton Muscatelli, Tiziano Ropele and Patrizio Tirelli, The Role of Fiscal Policy in a Monetary Union: Are National Automatic Stabilizers Effective?, March 2006

1683 Mario Jametti and Thomas von Ungern-Sternberg, Risk Selection in Natural Disaster Insurance - the Case of France, March 2006

1684 Ken Sennewald and Klaus Waelde, "Itô's Lemma" and the Bellman Equation for Poisson Processes: An Applied View, March 2006

1685 Ernesto Reuben and Frans van Winden, Negative Reciprocity and the Interaction of Emotions and Fairness Norms, March 2006

1686 Françoise Forges, The Ex Ante Incentive Compatible Core in Exchange Economies with and without Indivisibilities, March 2006

1687 Assar Lindbeck, Mårten Palme and Mats Persson, Job Security and Work Absence: Evidence from a Natural Experiment, March 2006

1688 Sebastian Buhai and Coen Teulings, Tenure Profiles and Efficient Separation in a Stochastic Productivity Model, March 2006

1689 Gebhard Kirchgaessner and Silika Prohl, Sustainability of Swiss Fiscal Policy, March 2006

1690 A. Lans Bovenberg and Peter Birch Sørensen, Optimal Taxation and Social Insurance in a Lifetime Perspective, March 2006

1691 Moritz Schularick and Thomas M. Steger, Does Financial Integration Spur Economic Growth? New Evidence from the First Era of Financial Globalization, March 2006

1692 Burkhard Heer and Alfred Maussner, Business Cycle Dynamics of a New Keynesian Overlapping Generations Model with Progressive Income Taxation, March 2006 
1693 Jarko Fidrmuc and Iikka Korhonen, Meta-Analysis of the Business Cycle Correlation between the Euro Area and the CEECs, March 2006

1694 Steffen Henzel and Timo Wollmershaeuser, The New Keynesian Phillips Curve and the Role of Expectations: Evidence from the Ifo World Economic Survey, March 2006

1695 Yin-Wong Cheung, An Empirical Model of Daily Highs and Lows, March 2006

1696 Scott Alan Carson, African-American and White Living Standards in the $19^{\text {th }}$ Century American South: A Biological Comparison, March 2006

1697 Helge Berger, Optimal Central Bank Design: Benchmarks for the ECB, March 2006

1698 Vjollca Sadiraj, Jan Tuinstra and Frans van Winden, On the Size of the Winning Set in the Presence of Interest Groups, April 2006

1699 Martin Gassebner, Michael Lamla and Jan-Egbert Sturm, Economic, Demographic and Political Determinants of Pollution Reassessed: A Sensitivity Analysis, April 2006

1700 Louis N. Christofides and Amy Chen Peng, Major Provisions of Labour Contracts and their Theoretical Coherence, April 2006

1701 Christian Groth, Karl-Josef Koch and Thomas M. Steger, Rethinking the Concept of Long-Run Economic Growth, April 2006

1702 Dirk Schindler and Guttorm Schjelderup, Company Tax Reform in Europe and its Effect on Collusive Behavior, April 2006

1703 Françoise Forges and Enrico Minelli, Afriat's Theorem for General Budget Sets, April 2006

1704 M. Hashem Pesaran, Ron P. Smith, Takashi Yamagata and Liudmyla Hvozdyk, Pairwise Tests of Purchasing Power Parity Using Aggregate and Disaggregate Price Measures, April 2006

1705 Piero Gottardi and Felix Kubler, Social Security and Risk Sharing, April 2006

1706 Giacomo Corneo and Christina M. Fong, What's the Monetary Value of Distributive Justice?, April 2006

1707 Andreas Knabe, Ronnie Schoeb and Joachim Weimann, Marginal Employment Subsidization: A New Concept and a Reappraisal, April 2006

1708 Hans-Werner Sinn, The Pathological Export Boom and the Bazaar Effect - How to Solve the German Puzzle, April 2006 